\title{
A study of the efficiency of spur gears made of powder metallurgy materials - ground versus super-finished surfaces
}

\author{
Xinmin $\mathrm{Li}^{*}$, Mario Sosa, Martin Andersson, Ulf Olofsson \\ Department of Machine Design, Royal Institute of Technology (KTH), SE 10044 Stockholm, Sweden
}

\section{A R T I C L E I N F O}

\section{Article history:}

Received 12 September 2015

Received in revised form

5 November 2015

Accepted 15 November 2015

Available online 22 November 2015

Keywords:

Powder metallurgy gear

Efficiency

Ground

Super-finished

\begin{abstract}
A B S T R A C T
Power loss is one of the main concerns in gear transmission systems. In this study a recirculating power back-to-back FZG test rig was used to investigate the efficiency of spur gears made of powder metallurgy (PM) material using two different surface manufacturing methods (ground and super-finished). The results were compared with previously presented results of standard gear material from the same test rig. The influence of the material (Wrought steel or PM) and surface roughness on the gear mesh efficiency and the total efficiency of the gearbox were analyzed in detail. The Young's modulus for PM materials is lower than for conventional gear steel. This may influence gear tooth bending and the efficiency of the gear transmission. Gear contact simulation results showed that the influence of gear tooth bending on PM gear transmission efficiency can be ignored in the FZG gear geometry. Higher surface energy combined with a smoother surface led to a lower transmission efficiency for the superfinished powder metallurgy gear combination compared to the standard gear material.
\end{abstract}

(c) 2015 Elsevier Ltd. All rights reserved.

\section{Introduction}

High fuel costs and the environmental concerns associated with energy utilization and air pollution have increased the importance of efficiency in gear transmission systems. High efficiency gear transmission systems generate less frictional heat, reduce the amount of oil needed for lubrication and can improve gear failure modes such as scoring and pitting. Means to attain "low loss" gear transmission systems include using light-weight gears, modifying tooth geometry to reduce specific sliding [1-3], using a gear oil that generates lower friction [4,5], or a combination of all three strategies.

Lots of studied have been done related to gear transmission efficiency. On the basis of traction measurements of combined rolling and sliding contact, Xiao et al. [6] reported that gear mesh power loss is lower for smooth surfaces than for rough surfaces. Britton et al. [7] reported that reducing the average surface roughness height from 0.4 to $0.05 \mu \mathrm{m}$ reduced gear mesh power loss by between $20 \%$ and $30 \%$. Simulating the rolling-sliding contact of gear tooth contact using twin-disc equipment, Bergseth et al. [8] showed that super-finished disks had enhanced friction and wear properties. Using ball-on-disc experimental studies, Björling et al. [9] showed that a super-finished surface has a large effect on friction and wear. Xiao et al. [10] used two rollers running against each other to simulate the friction force generated in gear-

\footnotetext{
${ }^{*}$ Corresponding author.
}

meshing processes and showed that fine ground $\left(S_{a}=0.3 \mu \mathrm{m}\right)$ surfaces showed better frictional properties than medium ground $\left(S_{a}=0.6 \mu \mathrm{m}\right)$ and rough ground $\left(S_{a}=1.2 \mu \mathrm{m}\right)$ surfaces. Sjöberg et al. [11] studied the influence of running-in on gear efficiency and showed that high running-in loads led to higher gear mesh efficiency. Andersson et al. [12] showed that super-finished gears exhibit overall higher efficiency than ground gears, but noted a distinct reversal phenomenon at low speeds.

Given the importance of energy and environmental concerns, it is important to pay attention to all aspects of a product including its manufacturing, operation, and maintenance. Powder metallurgy (PM) is usually used to manufacture parts with complex geometries such as gears and structural parts. Because of their light mass compared to wrought steel gears, PM gears may be classified as "low mass -low loss gears." There are, however, few publications dealing with the transmission efficiency of PM gears. Li et al. [13] used pin-on-disc experiments to show that regular steel (16MnCr5) disks on PM material pins, and PM material disks on PM material pins, had lower friction coefficients than regular steel disks on regular steel pins. On the basis of these results, Li et al. [14] investigated the gear mesh torque loss of regular steel gears and PM material gears. They found that running a standard material gear against a PM gear can improve efficiency. In addition the combination of PM with PM was more efficient than the standard on standard gear combination under intermediate load conditions (94 Nm, load stage 5 in a FZG gear test rig).

The bending stiffness of the gear teeth influences the points where the two surfaces contact each other. The Young's modulus 


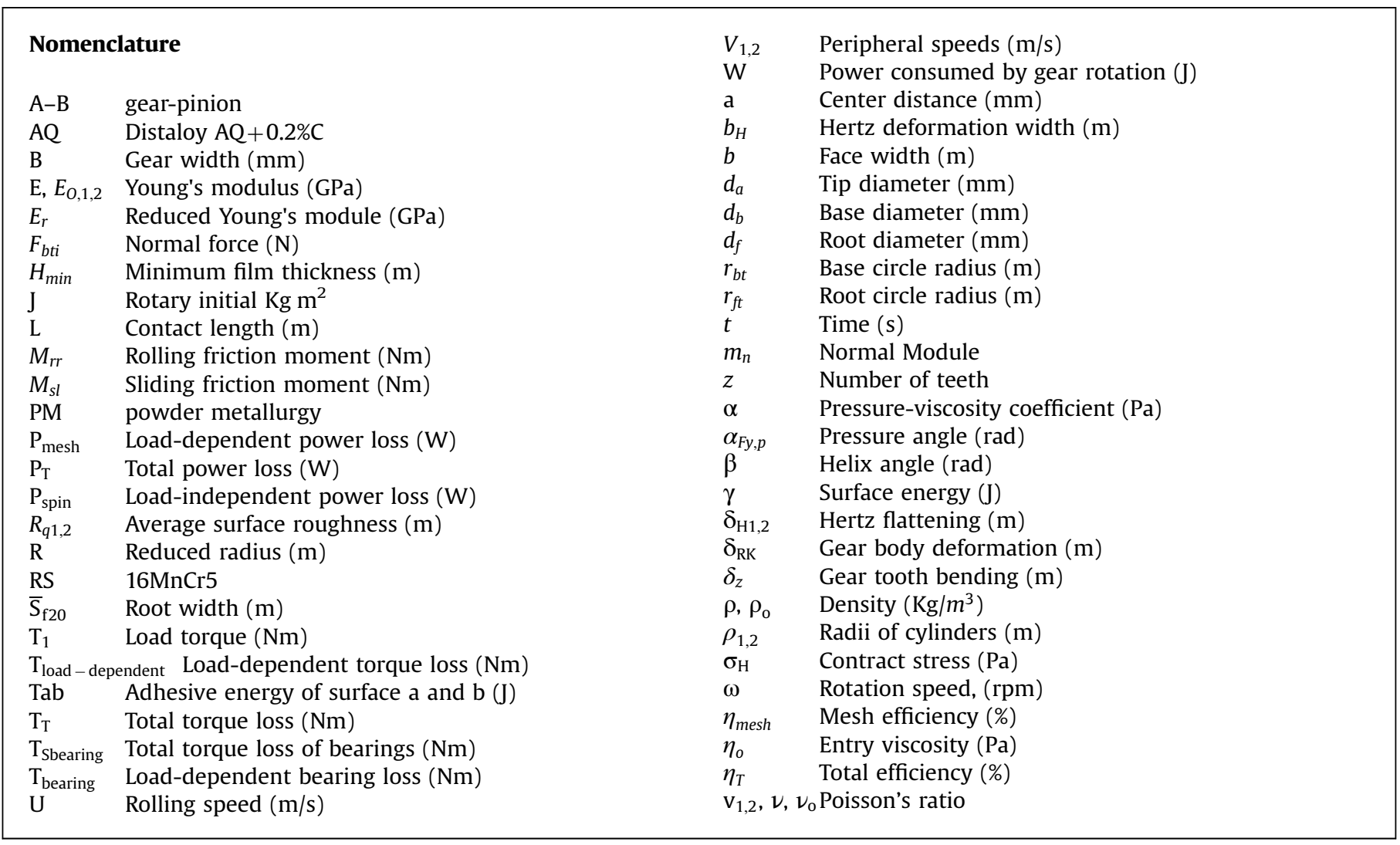

and Poisson's ratio $[13,14]$ of powder metallurgic materials are lower than those of standard gear steel, and this influences the bending stiffness. It is thus necessary to check whether these differences will alter the contact stress, sliding speeds, and film thickness at the contact point and so affect gearbox efficiency.

$\mathrm{Li}$ et al. [14] investigated the gear mesh torque loss of regular steel and PM material ground gears but the efficiency of superfinished PM gear are unknown. Using efficiency data for ground [11] and super-finished [12] regular steel gears as a base for further research, here we undertook additional research using the same test setup for super-finished gears made of PM material.

In this paper, two different surface manufacturing methods (ground and super-finished) are evaluated. The influence of material combination and surface roughness on total gearbox efficiency is analyzed. Surface analysis was performed on the gear flanks of all gears, for both the material and the surface manufacturing method.

\section{Experiments and experimental procedure}

\subsection{FZG gear test rig}

The test rig used in this experiment utilizes the power loop principle, also known as the four-square or back-to-back configuration, to provide a fixed torque (load) to a pair of precision test gears. As shown in Fig. 1 [15] the gear test rig consists of a slave gearbox and test gearbox connected by two shafts. One shaft has a load clutch to apply the load. The test gearbox contains a system for heating the test oil and controlling its temperature as well as a water-cooling system to assist in cooling the oil to the required starting temperature. A temperature sensor, which maintains a preset temperature, is located in the side of both the gearbox and slave gearbox. The test rig is powered by an electric motor at variable speeds up to $3500 \mathrm{rpm}$ and in two directions of rotation. The transmitted torque $\left(\mathrm{T}_{\mathrm{C}}\right)$, total torque loss $\left(\mathrm{T}_{\text {total }}\right)$, rotating speed $(\omega)$, and lubricant temperature $(T)$ are automatically measured and recorded as functions of time $(t)$. An FZG gear test rig has 14 load stages. For type $C$ gears, the Hertz contact pressure at the pitch point varies from $0.15 \mathrm{GPa}$ to $2.2 \mathrm{GPa}$, depending on the load stage. The use of this rig for efficiency studies is described in detail in Sjöberg et al. [11]. Andersson et al. [16] found the uncertainty in the torque measurements to be less than $0.05 \%$.

\subsection{Test specimens and lubricant}

The gear specimens used in this experiment are type $C$ gears with tip relief. Tip relief enables gears gradually entry into mesh and thus reduce dynamic loadings and makes gear drives operate quietly. The gears are made of PM materials with two different tooth surface manufacturing methods (ground and super-finished) as shown in Fig. 2. In all other respects they are the same. The PM gear material is Distaloy $A Q+0.2 \% C$. The chemical composition of $16 \mathrm{MnCr} 5$ (used in Sjöberg et al. [11] and Andersson et al. [12]) and the PM gear materials is shown in Table 1. In the rest of this paper, $\mathrm{AQ}$ RS and $\mathrm{A}-\mathrm{B}$ will be used to identify Distaloy $\mathrm{AQ}+0.2 \% \mathrm{C}$, $16 \mathrm{MnCr} 5$, and the gear-pinion combination, respectively. AQ gears were sintered for $45 \mathrm{~min}$ at $1120{ }^{\circ} \mathrm{C}$ in a $90 \%$ nitrogen and $10 \%$ hydrogen atmosphere. The standard gear steel, $16 \mathrm{MnCr} 5$, is a wellknown wrought steel with easily identified elastic properties. For the sintered steels, the situation is more complicated. PM materials are porous, and the way they are manufactured determines their porosity and thus their density and mechanical properties. According to Beiss [17], the elastic properties of powder metal steel materials can be calculated using the following formulas:

$\mathrm{E}=\mathrm{E}_{\mathrm{o}}\left(\frac{\rho}{\rho_{\mathrm{o}}}\right)^{3.4}$ 
$\mathrm{v}=\left(\frac{\rho}{\rho_{\mathrm{o}}}\right)^{0.16}\left(1-v_{0}\right)-1$

where $\rho_{0}, E_{0}$, and $\nu_{0}$ are the density, Young's modulus, and Poisson's ratio of solid steel, respectively. Table 2 shows the material characteristics of $16 \mathrm{MnCr} 5$ and PM gears.

The most important parameters of the specimens are shown in Table 3. Note that the PM gear has the same surface manufacture methodology (grinding and super-finishing) as the previously presented regular steel gears $[11,12]$. The scope of the test

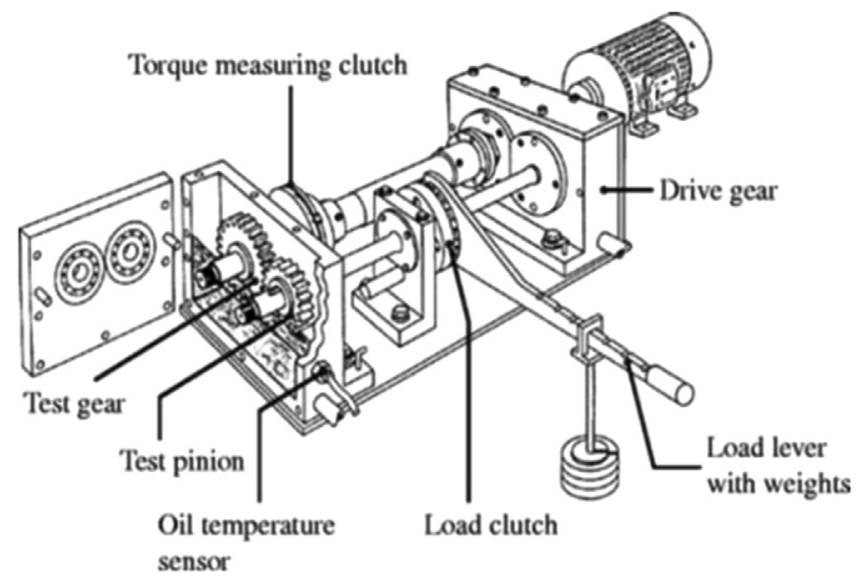

Fig. 1. Schematic layout of FZG spur gear efficiency test rig [15].

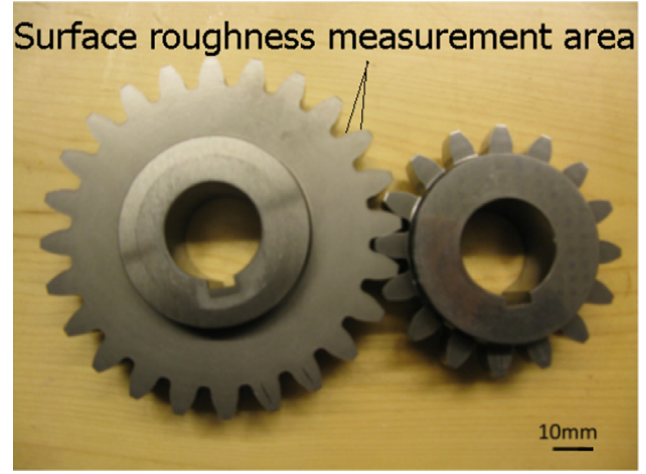

Fig. 2. Experimental test gears.

Table 1

Chemical composition (mass\%) of $16 \mathrm{MnCr} 5$ gears and PM gears.

\begin{tabular}{llllllllll}
\hline & $\mathrm{Ni}$ & $\mathrm{Mn}$ & $\mathrm{Fe}$ & $\mathrm{C}$ & $\mathrm{S}$ & $\mathrm{P}$ & $\mathrm{Si}$ & $\mathrm{Cr}$ & $\mathrm{Mo}$ \\
\hline $\mathrm{RS}$ & - & $1-1.3$ & $96.95-98.78$ & $0.14-0.19$ & $\leq 0.035$ & $\leq 0.025$ & 0.4 & 1.1 & - \\
$\mathrm{AQ}$ & 0.5 & - & 98.8 & 0.2 & - & - & - & - & 0.5
\end{tabular}

Table 2

Characteristics of the specimens.

\begin{tabular}{lll}
\hline & $16 \mathrm{MnCr} 5$ & PM \\
\hline Young's modulus (GPa) & 210 & 154 \\
Poisson's ration & 0.3 & 0.28 \\
Density $\left(\frac{\mathrm{kg}}{\mathrm{m}^{3}}\right)$ & 7805 & 7200 \\
Mass $($ gear/pinion) $(\mathrm{g})$ & $1201.27 / 630.89$ & $1106.80 / 583.67$ \\
\hline
\end{tabular}

Table 3

The main parameters of gear specimens.

\begin{tabular}{llll}
\hline & Symbol & Pinion & Gear \\
\hline Number of teeth & $\mathrm{z}$ & 16 & 24 \\
Normal module & $m_{n}$ & 4.5 & 4.5 \\
Gear width $(\mathrm{mm})$ & $b$ & 14 & 14 \\
Pressure angle $(\mathrm{deg})$ & $\alpha$ & $20^{\circ}$ & $20^{\circ}$ \\
Reference diameter $(\mathrm{mm})$ & $d$ & 72 & 108 \\
Base diameter $(\mathrm{mm})$ & $d_{B}$ & 67.65 & 101.48 \\
Tip diameter $(\mathrm{mm})$ & $d_{a}$ & 82.46 & 118.36 \\
Root diameter $(\mathrm{mm})$ & $d_{f}$ & 61.34 & 98.98 \\
Center distance $(\mathrm{mm})$ & $a$ & 91.5 & 91.5 \\
Start tip relief $(\mathrm{mm})$ & $d_{A}$ & 80.3 & 115.9 \\
Tip relief $(\mu \mathrm{m})$ & $\mathrm{TR}$ & 20 & 20 \\
Addendum modification factor & $X 1, X 2$ & 0.1817 & 0.1715 \\
\hline
\end{tabular}

Table 4

The main characteristics of the lubricant.

\begin{tabular}{ll}
\hline Lubricant name & BP Castrol Syntrans 75W-80 \\
\hline Kinematic viscosity at $40{ }^{\circ} \mathrm{C}\left(\mathrm{mm}^{2} / \mathrm{s}\right)$ & 64.1 \\
Kinematic viscosity at $100{ }^{\circ} \mathrm{C}\left(\mathrm{mm}^{2} / \mathrm{s}\right)$ & 11.8 \\
\hline
\end{tabular}

Table 5

Efficiency test procedure of AQ-AQ AQ-RS and RS-RS combinations.

\begin{tabular}{|c|c|c|c|}
\hline $\begin{array}{l}\text { Gear material } \\
\text { combination }\end{array}$ & $\begin{array}{l}\text { Load (Nm) } \\
\text { (Load stage) }\end{array}$ & $\begin{array}{l}\text { Gear speed }(\mathrm{rpm})(\text { Pitch } \\
\text { line velocity }(\mathrm{m} / \mathrm{s}))\end{array}$ & $\begin{array}{l}\text { Gear surface } \\
\text { furnish }\end{array}$ \\
\hline \multirow[t]{9}{*}{ AQ-AQ RS-RS } & & $0(0)$ & GR and SF \\
\hline & & $87(0.5)$ & \\
\hline & & $174(1)$ & \\
\hline & $0(\mathrm{LO})$ & $348(2)$ & \\
\hline & 94.1 (L5) & $550(3.2)$ & \\
\hline & 183.4 (L7) & $1444(8.3)$ & \\
\hline & & $1740(10)$ & \\
\hline & & 2906 (15) & \\
\hline & & $3479(20)$ & \\
\hline
\end{tabular}

program was limited to investigation of the impact of gear material and surface finish amplitude on spur gear efficiency. The lubricant used in this experiment contains multifunctional additives required for mild extreme-pressure conditions. The main characteristics of the lubricant are measured and shown in Table 4.

\subsection{Test procedure}

All the tests were performed using the same procedure with new specimens but at different load stages as [11] and [12]. The pitch velocities tested were $0.5,1,2,3.2,8.3,10,15$, and $20 \mathrm{~m} / \mathrm{s}$. The loads were $0,94.1$, and $183.4 \mathrm{Nm}$ for both RS-RS and AQ-AQ combinations. Each test was performed three times to ensure repeatability. The specimens were run-in for $4 \mathrm{~h}$ at load stage 5 (applied torque $94 \mathrm{Nm}$ ) with a rotating speed of $87 \mathrm{rpm}$ at a controlled temperature of $90^{\circ} \mathrm{C}$. The same lubricant was used during running-in and during the efficiency experiments. Both the test gearbox and the slave gearbox contained $1500 \mathrm{~mL}$ lubricant. After running-in, the efficiency tests were performed according to the test procedures shown in Table 5. The experimental period was 5 min. In the remainder of this paper GR and SF will be used to identify ground and super-finished gears.

\section{Efficiency calculation from measured $T_{T}$}

The calculation procedure used was that of Sören et al. [11]. Because of the complex mechanical and fluid-mechanical 

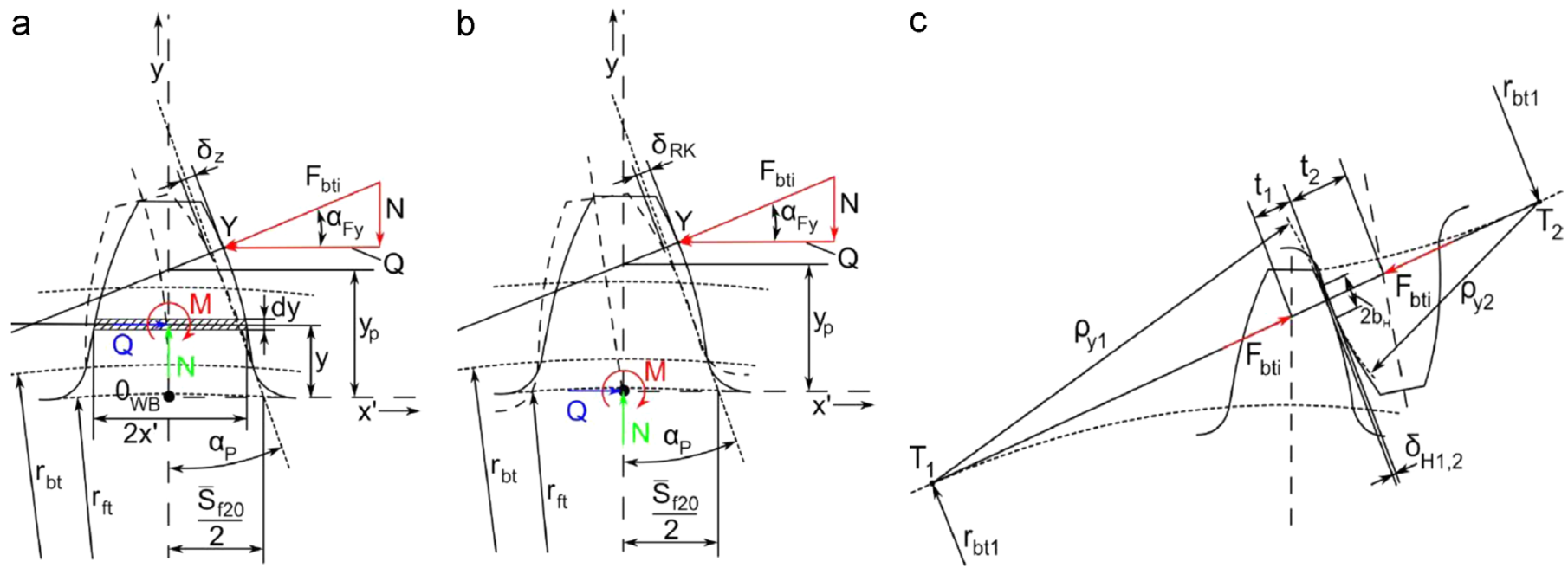

Fig. 3. Schematic of (a) gear tooth bending, (b) gear body deformation and (c) Hertz flattening [20].

interactions in a dip-lubricated gearbox, there are a large number of power loss sources such as gear tooth mesh loss, air windage losses, oil churning loss, and rotating seals and bearings losses. Usually the gear torque losses are classified as load-dependent and load-independent power losses as shown in equation (3). Loadindependent losses are associated with moving parts immersed in the lubricant, while load-dependent power losses result from contacting bodies with relative movement. The main sources of frictional losses are the gears and the roller bearings.

$\mathrm{T}_{\mathrm{T}}=\mathrm{T}_{\text {load }- \text { dependent }=+} \mathrm{T}_{\text {load }}-$ independent

where $T_{T}$ is the measured total torque loss. $T_{\text {load-dependent }}$ is the load-dependent torque loss including gear tooth mesh loss and friction losses of bearings. $\mathrm{T}_{\text {load-independent }}$ is the load-independent power loss, which includes oil churning loss, air windage loss, and rotating seals and bearings losses. In order to distinguish loaddependent and load-independent torque losses experimentally, a two-step measurement procedure was adopted. First the total torque loss $\mathrm{T}_{\mathrm{T}}$ is measured under no load at a certain test condition. Then the same test is repeated under a given transmitted torque $\left(T_{C}\right)$ with all other conditions the same. When $T_{C}=0$, the load-dependent portion is approximately zero $\left(\mathrm{T}_{\text {load-dependent }} \approx 0\right.$ ),

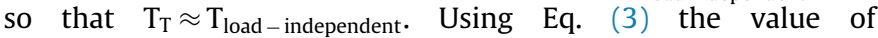
$\mathrm{T}_{\text {load-dependent }}$ for different $\mathrm{T}_{C}$ can be obtained. In order to estimate the gear mesh torque loss, the load-dependent bearing torque loss must be removed from $T_{\text {load-dependent }}$. Load-dependent bearing loss is composed of rolling and sliding loss. It was estimated using Eq. (4) [18].

$T_{\text {bearing }}=M_{r r}+M_{s l}$

$M_{r r}$ is rolling friction moment:

$M_{r r}=\varphi_{i s h} \varphi_{r s G_{r T}(v n)^{0.6}}$

$M_{s l}$ is sliding friction moment:

$M_{s l}=G_{s l} \mu_{s l}$

The FZG gear test rig altogether has 8 NJ406 cylindrical roller bearings, four on the pinion side and four on the gear side. Bearing friction moment losses from the pinion side $\left(T_{\text {bearingSKF1 }}\right)$ and the gear side ( $T_{\text {bearingSKF2 }}$ ) were multiplied by the angular velocity of their respective shafts $\left(\omega_{1}\right)$ and $\left(\omega_{2}\right)$. The power losses for the eight bearings ( $T_{\text {Sbearing }}$ ) were then added together and divided by the ingoing angular velocity from the motor $\left(\omega_{2}\right)$ in the following manner:

$T_{\text {Sbearing }}=4\left(\frac{T_{\text {bearingSKF1 }} \omega_{1}+T_{\text {bearingSKF2 }} \omega_{2}}{\omega_{2}}\right)$
So the gear mesh torque loss $T_{\text {mesh }}$ can be obtained.

$T_{\text {mesh }}=T_{\text {load }}-$ dependent $=-T_{\text {bearing }}$

Gearbox total efficiency $\left(\eta_{T}\right)$ was calculated using Eq. (9) from Petry-Johnson [3], dividing the measured torque loss by the nominal torque transferred by the pinion $\left(T_{1}\right)$ and multiplying by 0.5 for the efficiency of one gearbox. The gear mesh torque loss was calculated as in Eq. (10). The gear mesh efficiency was calculated by dividing the gear mesh torque loss by the nominal torque and gear ratio $(u)$ and multiplying by 0.5 for the efficiency of one gear mesh. This in essence assumes that both gearboxes have the same power loss.

$\eta_{T}=1-0.5=\left(\frac{T_{T}}{u T_{1}}\right)$

$T_{\text {mesh }}=T_{\text {load-dependent }}-T_{\text {Sbearing }}$

$\eta_{\text {mesh }}=1-0.5\left(\frac{T_{\text {mesh }}}{u T_{1}}\right)$

In order to quantify the gain (or loss) due to different material gear combinations or surface roughnesses, the following equation was used. The result is a percentage.

$\Delta_{\eta}=100\left(\frac{\eta_{1}-\eta_{2}}{1-\eta_{1}}\right)$

\section{Gear contact mechanics calculation}

The differences in the elastic properties of powder metal and regular gear steel materials (shown in Table 2) could lead to different values of contact stress, sliding speed, and film thickness between RS-RS and AQ-AQ gear combinations. Due to the differences in the Young's modulus and Poisson's ratio between PM and RS materials, the path of contact (coordinate on the line of action) and the normal load distribution of PM and RS gears could be different. The calculation of the path of contact was performed using the gear calculation software Kisssoft (Kisssoft 03/2014). Using geometric parameters [19] Kisssoft also takes into account the deformations of gear body, gear tooth bending, and Hertz contact, as illustrated in Fig. 3. Kisssoft also calculates the normal load distribution.

The gear tooth bending $\delta_{Z}$, gear body deformation $\delta_{R K}$, and Hertz flattening $\delta_{H 1,2}$ are calculated by Kisssoft according to Eqs. 


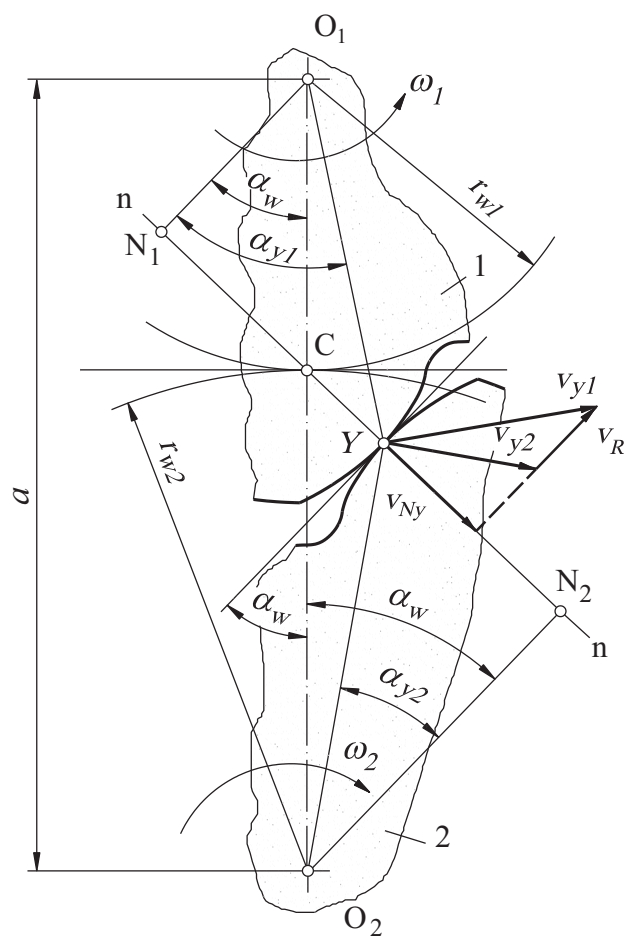

Fig. 4. Rolling of two gear profiles accompanied by simultaneous rotation [19].

(13), (14), and (15) respectively:

$$
\begin{aligned}
\delta_{z}= & \frac{F_{b t i}}{b}\left(\cos \alpha_{F y}\right)^{2} \frac{1-v^{2}}{E}\left[12 \int_{0}^{y_{P}} \frac{\left(y_{P-y}\right)^{2}}{\left(2 X^{\prime}\right)^{3}} d y\right. \\
& \left.+\left(\frac{2.4}{1-v}+\left(\tan \alpha_{F y}\right)^{2}\right) \int_{0}^{y_{P}} \frac{d y}{2 X^{\prime}}\right]
\end{aligned}
$$

$$
\begin{aligned}
\delta_{R K}= & \frac{F_{b t i}}{b}\left(\cos \alpha_{F y}\right)^{2} \frac{1-v^{2}}{E}\left[\frac{18}{\pi} \frac{y_{P}^{2}}{S_{f 20}^{2}}+\frac{2(1-2 v)}{1-v}-\frac{y_{P}}{S_{f 20}}\right. \\
& \left.+\frac{4.8}{\pi}\left(1+\frac{1-v}{2.4}\left(\tan \alpha_{F y}\right)^{2}\right)\right]
\end{aligned}
$$

$$
\delta_{H 1,2}=\frac{F_{b t i}}{\pi b}\left[\left|\frac{1-v_{1}^{2}}{E_{1}} \ln \left(\frac{b_{H}^{2}}{4 t_{1}^{2}}\right)+\frac{v_{1}\left(1+v_{1}\right)}{E_{1}}\right|+\left|\frac{1-v_{2}^{2}}{E_{2}} \ln \left(\frac{b_{H}^{2}}{4 t_{2}^{2}}\right)+\frac{v_{2}\left(1+v_{2}\right)}{E_{2}}\right|\right]
$$

The theoretical radius $\rho_{y}$ of different points on the gear tooth profile can be calculated according to the geometric parameters, as detailed in [19]. The actual radius $\rho$ is:

$\rho=\rho_{y}-\delta_{z}-\delta_{R K}-\delta_{H 1,2}$

In addition $\rho$ will also be the coordinate of the corresponding point on the line of action. For some points it is easier to calculate the corresponding radii $\rho_{y}$ of the meshed gear tooth. Then $N_{1} N_{2}$ $-\rho$ will be the coordinate of the point. $N_{1} N_{2}$ is the length of the line of action as shown in Fig. 4.

The contact stress calculation between two cylinders can be used to calculate the contact stress of an arbitrarily curved surface by substituting the radii of the surfaces at the contact line. This approximation is used here to calculate the maximum contact stress $\sigma_{H}[19]$ for the gear tooth contact:

$$
\sigma_{H}=\sqrt{\frac{1}{\pi\left(\frac{1-v_{1}^{2}}{E_{1}}+\frac{1-v_{2}^{2}}{E_{2}}\right)} \frac{F_{b t i}}{b \frac{\rho_{1} \rho_{2}}{\rho_{1}+\rho_{2}}}}
$$

As shown in Fig. 4, during the meshing process as the contact point moves over the path of contact defined by the shape of the profiles, the angles $\alpha_{y 1}$ and $\alpha_{y 2}$ vary, just like the radii $r_{y 1}\left(O_{1} Y\right)$ and $r_{y 2}\left(\mathrm{O}_{2} Y\right)$. The peripheral speeds of point $\mathrm{Y}$ as the point of profile 1 and 2 are

$V_{1}=r_{y 1} \omega_{1}$

$V_{2}=r_{y 2} \omega_{2}$

The difference of the speeds in the tangent direction of the profiles is called the mated profiles sliding speed and is

$V=\left|r_{y 1} \omega_{1} \sin \alpha_{y 1}-r_{y 2} \omega_{2} \sin \alpha_{y 2}\right|$

The line contact EHD model [21] of Dowson and Higginson was used to calculate the film thickness:

$H_{\text {min }}=1.654 \frac{\left(\eta_{0} U\right)^{0.7} R^{0.43} \alpha^{0.54} L^{0.13}}{E_{r}^{0.03} F^{0.13}}$

The model of Dowson and Higginson does not take surface roughness effects into account.

\section{Results}

\subsection{Efficiency results}

The results relating to gear efficiency are presented in terms of gear total efficiency with mean value and standard deviation.

Fig. 5 shows the total efficiency results of both AQ-AQ and RSRS gear combinations. Note that the efficiency results for the RS-RS gear combination are extracted from [11,12]. Looking at the graph one can identify different speed regions where, for instance, the AQ powder metallurgic material performs better than the standard gear material. Therefore, in order to compare the trend of efficiency, different speed ranges are used here and also in the discussion. At pitch velocities from 1 to $20 \mathrm{~m} / \mathrm{s}$, the average total efficiency calculated by Eq. (9) was 7\% higher for the ground AQAQ gear combinations than for RS-RS gear combinations at load stage 5 . For load stage 7 at pitch velocities from 0.5 to $8.3 \mathrm{~m} / \mathrm{s}$, the total efficiency of AQ-AQ gear combinations is 6.3\% lower than that of RS-RS. At pitch velocities from 10 to $20 \mathrm{~m} / \mathrm{s}$, the AQ-AQ and RSRS gear combinations have nearly the same average total efficiency.

For the RS-RS ground and super-finished gear combinations between pitch point velocities 2 and $20 \mathrm{~m} / \mathrm{s}$, the average total efficiency was $19 \%$ and $16 \%$ higher for the super-finished gear combinations than for the ground gears at load stages 5 and 7 , respectively. As for the super-finished AQ-AQ gear combinations, the trend is totally different from that of RS-RS material gear combinations. At pitch velocities from 0.5 to $20 \mathrm{~m} / \mathrm{s}$, the average total efficiency was $24 \%$ and $32 \%$ lower for super-finished AQ-AQ gear combinations than for ground gears at load stages 5 and 7 (L5 and L7) respectively. Note that the super-finished AQ-AQ combination shows the lowest total efficiency compared with that of super-finished RS-RS, ground RS-RS, and ground AQ-AQ combinations.

Fig. 6 shows the gear mesh efficiency. Above a pitch velocity of $1 \mathrm{~m} / \mathrm{s}$ the AQ-AQ ground gear combination always shows higher mesh efficiency than RS-RS at L5. The average gear mesh efficiency was 7\% higher for ground AQ-AQ gear combinations than RS-RS. At load stage 7 over the whole speed range, the average gear mesh efficiency of RS-RS is $9 \%$ higher than that of AQ-AQ. The gear mesh efficiency was $60 \%$ and $33 \%$ higher for super-finished RS-RS gear combinations than for ground gears at L5 and L7, respectively, at pitch line velocities between 3 and $20 \mathrm{~m} / \mathrm{s}$ [11,12]. The trend for AQ-AQ gear combinations is totally different: $27 \%$ and $30 \%$ lower 


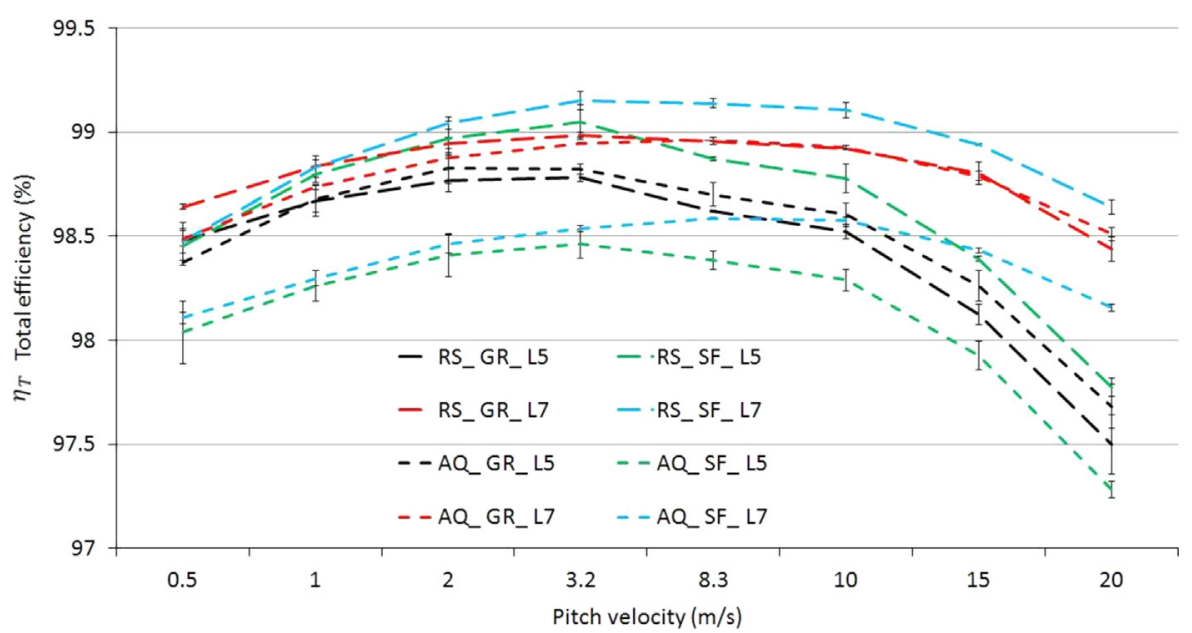

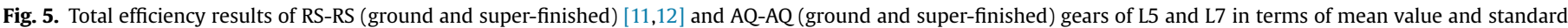
deviation.

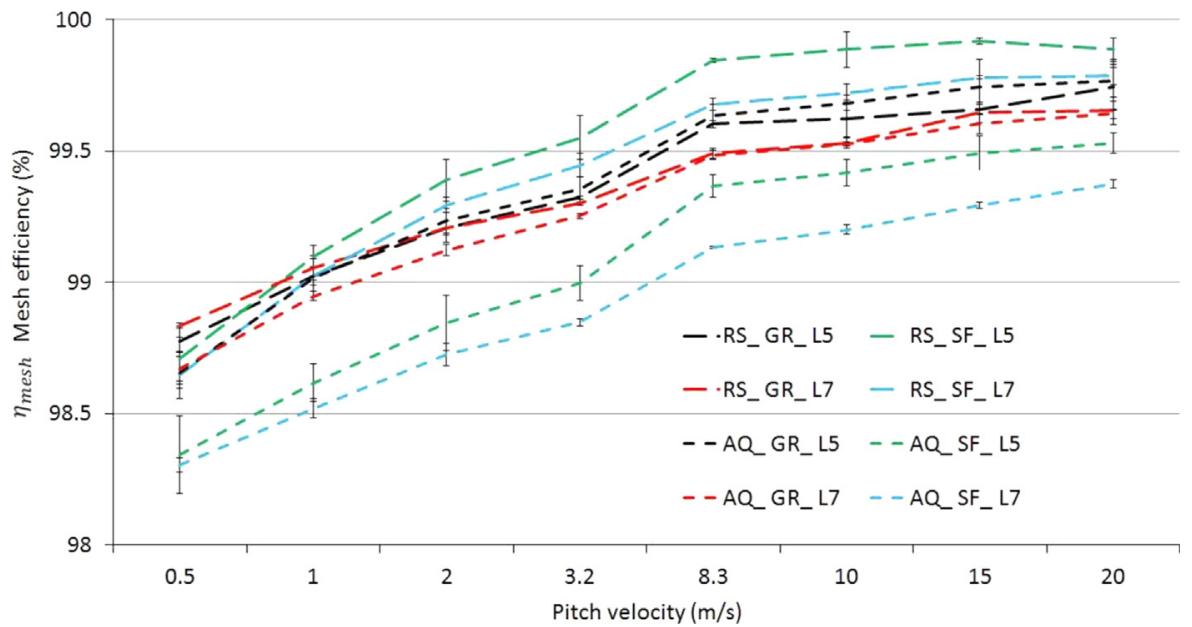

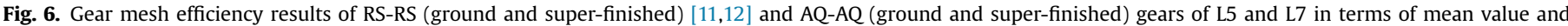
standard deviation.

for super-finished AQ-AQ gear combinations than for ground gears at L5 and L7, respectively. Note that the super-finished AQ-AQ combination also shows the lowest mesh efficiency compared to super-finished RS-RS, ground RS-RS, and ground AQ-AQ combinations.

\subsection{Surface analysis}

5.2.1. 3D surface roughness and amplitude parameters of gear tooth

Fig. 7 presents the 3D surface roughness and peak distribution results for the gear flanks (the surface roughness measurement area is shown in Fig. 2). The surface roughness before testing are shown in a, b, c, and d. After testing roughness is shown in e, f, $g$, and $h$. The measured area is $4.5 \times 2 \mathrm{~mm}^{2}$. The ordinate is the height of the asperities and the abscissa is the quantity in percentage of asperities. The accented figures (e.g. a') in Fig. 7 are the Abbott-Firestone curves for each case. In addition, the surface amplitude parameters in terms of Sa and Sz for ground and superfinished gear flanks are shown in Tables 6 and 7 respectively.

For ground RS-RS and AQ-AQ gear combinations the surface topography is nearly the same before and after test. One thing to note is that for the super-finished AQ-AQ gears, the surface roughness and peak distribution have deteriorated. As shown in Table 7, the surface amplitude parameter of $S_{a}$ increased somewhat from 0.13 to $0.15 \mu \mathrm{m}$. The same information in terms of peak distribution and surface roughness is shown in Fig. $7 d, d^{\prime}, h$ and $h^{\prime}$. The main peak height of the initial super-finished AQ material tooth is $0.6,0.7$, and $0.8 \mu \mathrm{m}$ (Fig. $7 \mathrm{~d}^{\prime}$ ), but it is $1.2,1.3$, and $1.4 \mu \mathrm{m}$ after the experiment (Fig. $\left.7 h^{\prime}\right)$.

\subsubsection{Porosity structure of $A Q$ material gear tooth}

Fig. 8 shows an optical micrograph of a cut section of the AQ material gear tooth showing porosities on or near the surface. $\mathrm{Li}$ et al. [14] showed that the porosities of AQ can lower the friction coefficient of pin-on-disc experiment and gear mesh torque loss of FZG gear efficiency experiment.

\subsubsection{SEM micrographs of gear flanks}

Fig. 9 shows the SEM micrographs of the gear flanks of both ground and super-finished gears. For ground gears, the tracks parallel to the grinding direction are caused by the manufacturing method. The micrographs demonstrate that the RS-RS combination has heavier adhesive wear than the AQ-AQ combination for ground gears. The porosities can also be seen on the surface of the AQ gear flanks.

As for the super-finished gears, the RS-RS gear combination has numerous small wear scratches which indicate abrasive wear while the AQ-AQ combination shows heavy adhesive wear material transfer covering nearly the whole photo, as shown in Fig. $9 d$. 
a

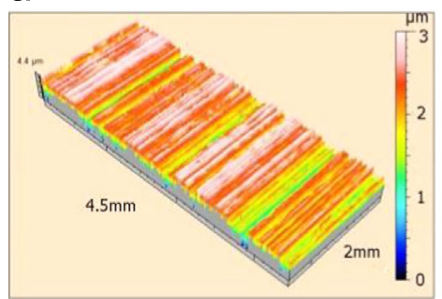

RS-GR

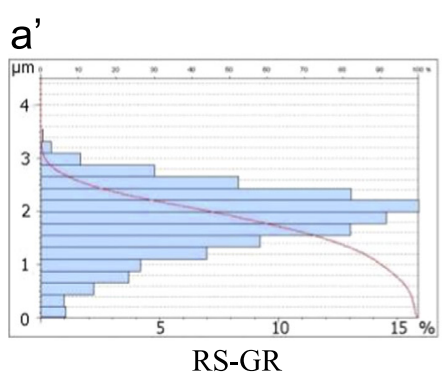

e

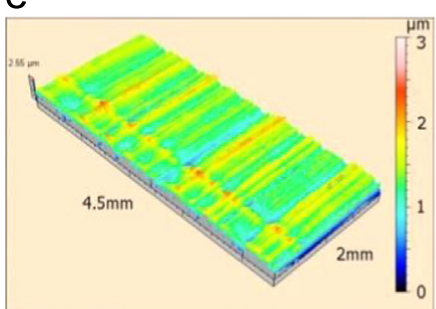

RS-RS-GR

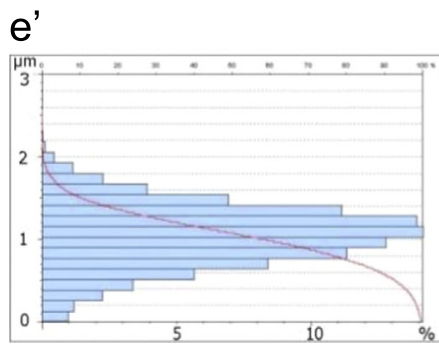

RS-RS-GR b

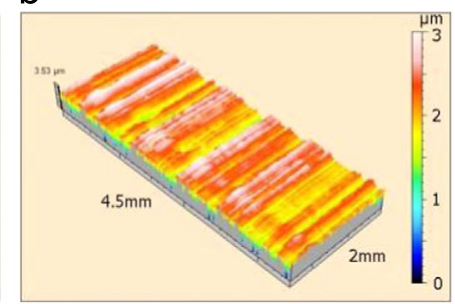

AQ-GR

b'

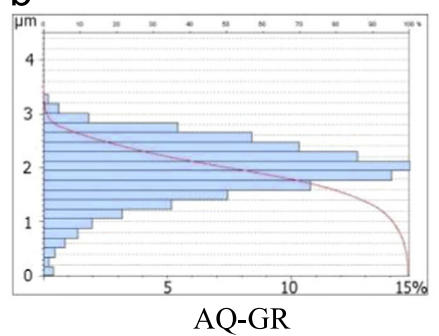

f

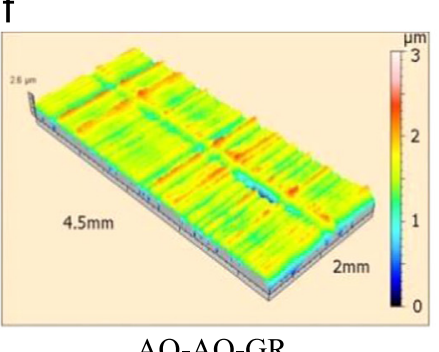

AQ-AQ-GR

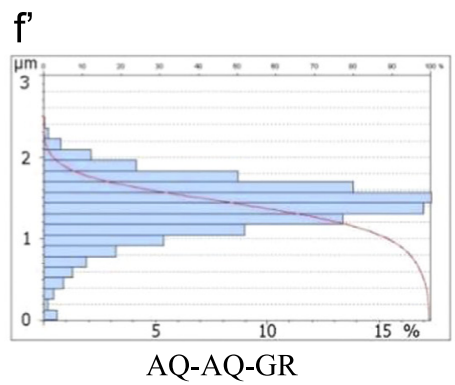

C

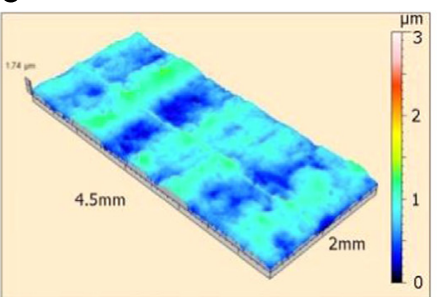

RS-SF

c'

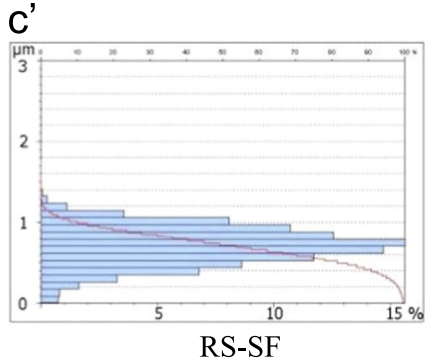

g

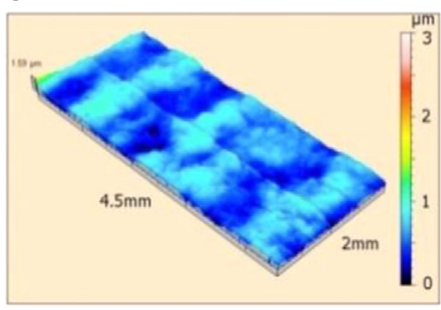

RS-RS-SF

g'

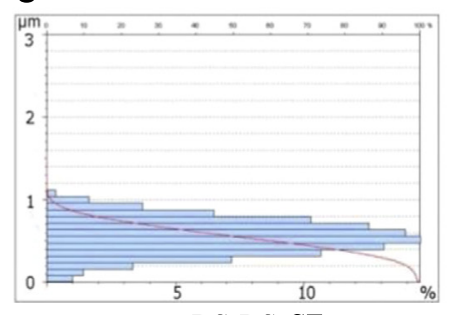

RS-RS-SF d

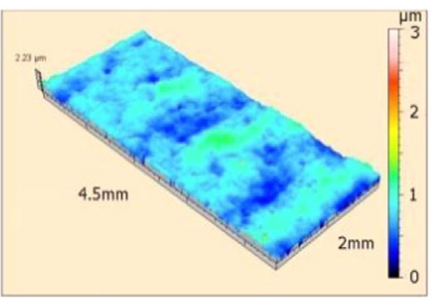

AQ-SF

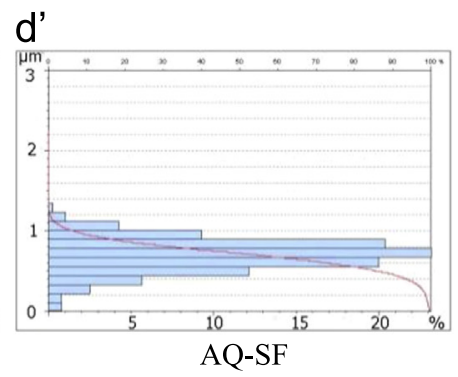

$\mathrm{h}$

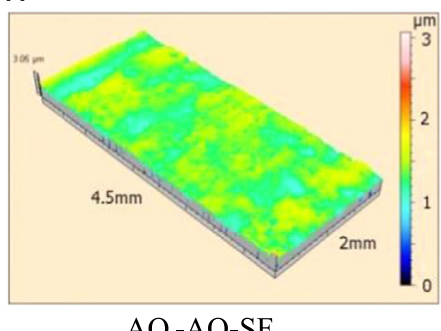

AQ -AQ-SF

h'

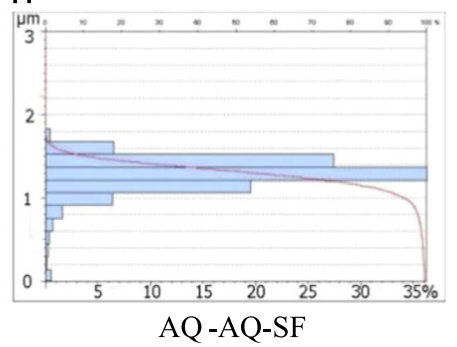

Fig. 7. 3D surface roughness and peak distribution results of gear flanks.

Table 6

Surface amplitude parameters of ground gear flanks.

\begin{tabular}{llllll}
\hline Surface amplitude parameter & \multicolumn{2}{l}{ RS-RS combination } & & \multicolumn{2}{l}{ AQ-AQ combination } \\
\cline { 2 - 3 } \cline { 5 - 6 } \cline { 5 - 6 } & Initial & After test & & Initial & After test \\
\hline Sa $(\mu \mathrm{m})$ & 0.35 & 0.29 & & 0.34 & 0.26 \\
Sz $(\mu \mathrm{m})$ & 3.85 & 2.39 & & 3.46 & 2.52 \\
\hline
\end{tabular}

Table 7

Surface amplitude parameters of super-finished gear flanks.

\begin{tabular}{llllll}
\hline Surface amplitude parameter & \multicolumn{2}{l}{ RS-RS combination } & & \multicolumn{2}{l}{ AQ-AQ combination } \\
\cline { 2 - 3 } \cline { 5 - 6 } \cline { 5 - 6 } & Initial & After test & & Initial & After test \\
\hline $\mathrm{Sa}(\mu \mathrm{m})$ & 0.15 & 0.14 & & 0.13 & 0.15 \\
$\mathrm{Sz}(\mu \mathrm{m})$ & 1.23 & 1.14 & & 1.73 & 1.46 \\
\hline
\end{tabular}

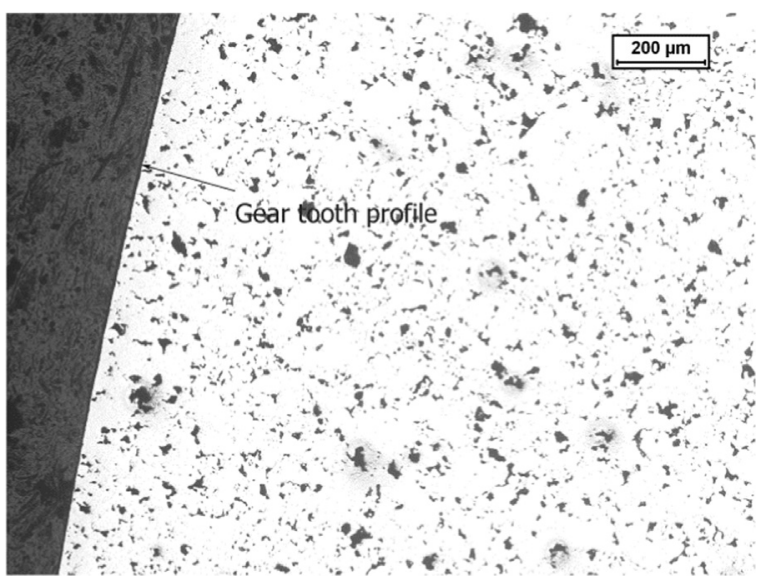

Fig. 8. Micrographs of cut section of $A Q$ material ground gear. 
a

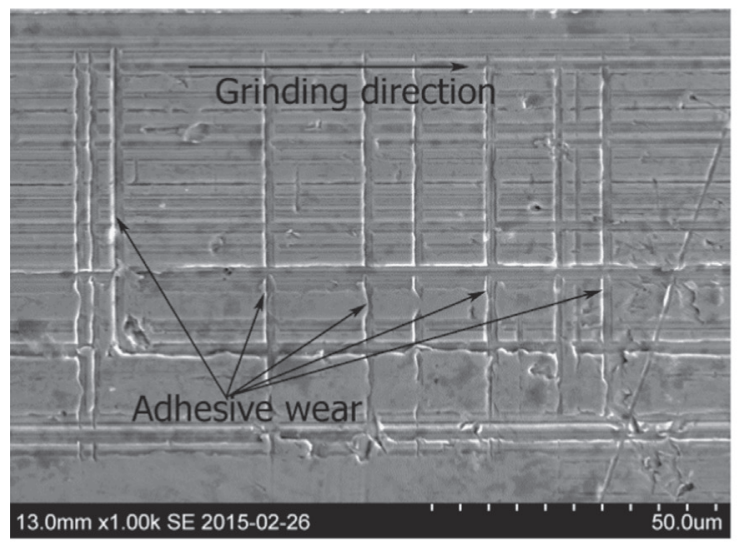

RS-RS-GR

C

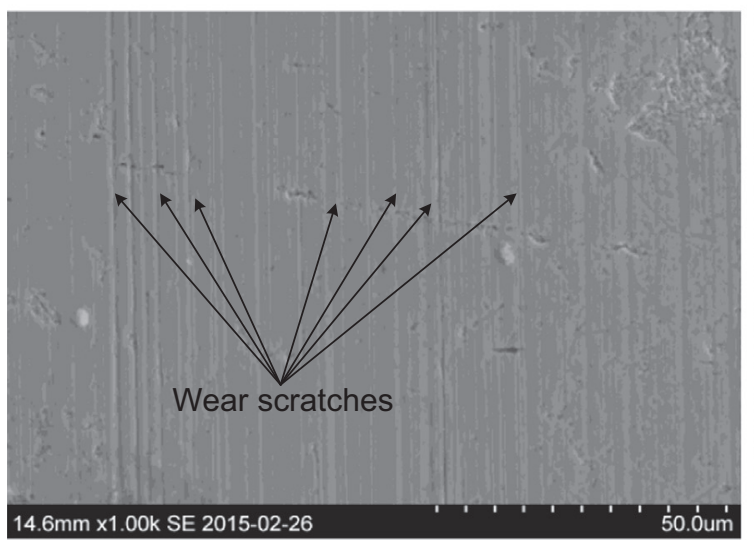

RS-RS-SF b

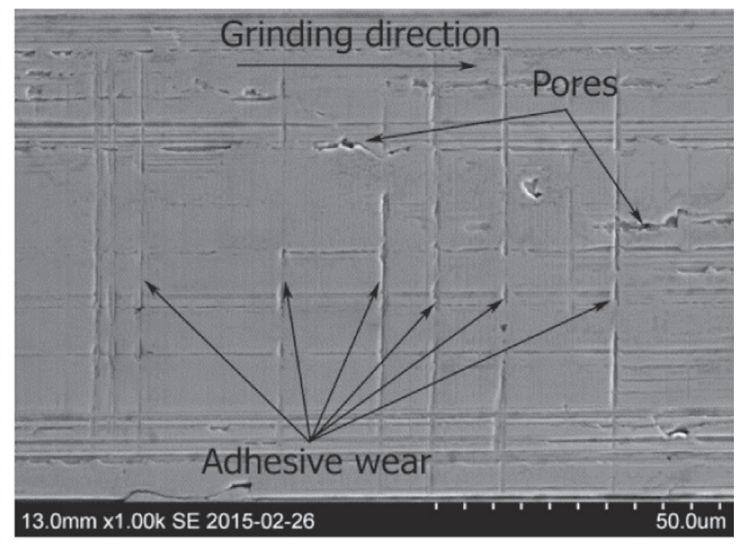

AQ-AQ-GR

d

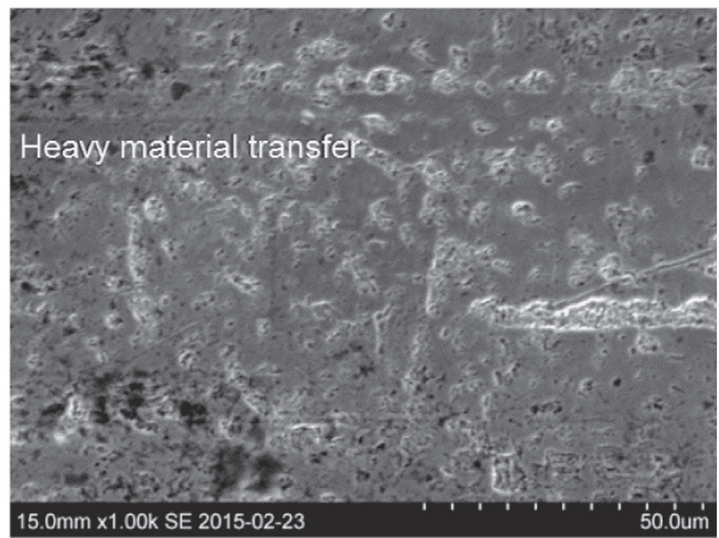

AQ-AQ-SF

Fig. 9. SEM micrographs of gear flanks.

5.2.4. Calculation results of contact stress, sliding speed, and film thickness

Fig. 10 shows the normal load and maximum contact stress of the RS-RS and AQ-AQ gear combinations at load stage 7. For the normal load, the biggest difference appears at the start and end point of meshing because of the gear deformation. Overall the maximum contact stress of the AQ-AQ gear combination is lower than that of the RS-RS due to the larger Hertz contact deformation. The X-coordinate (for example $N_{1} Y$ as shown in Fig. 4) is the distance from point $N_{1}$ to the contact point of the two-gear profile on the line of action $\mathrm{N}_{1} \mathrm{~N}_{2}$. Here the starting point of gear mesh of the driving gear is defined as $\mathrm{A}$; the double mesh region is between $B$ and D. C is the pitch point and is located between B and $D$. $E$ is the end point of meshing. For PM and RS material gears, the $\mathrm{X}$-coordinate is different due to the difference in gear deformation. The coordinate of mesh points on the line of action is shown in Table 8. These mesh points are also the X-coordinates of Figs. 10,11, and 12. From Table 8 it can be seen that the coordinate of the PM and RS gears differs only after the first decimal.

Figs. 11 and 12 present the mated profiles sliding speed and film thickness of RS-RS and AQ-AQ gear combinations at load stage 7 for two different rotational speeds: 3479 and $87 \mathrm{rpm}$. Both gear combinations have nearly the same sliding speeds, as shown in Fig. 11. Note that the calculation of sliding speed also takes the gear deformation into account. Different X-coordinates of the mesh point on the line of action will lead to different $r_{y 1}$ and $r_{y 2}$ for PM and RS gears, as shown in Fig. 4. In most of the contact, the
Table 8

Coordinate of mesh points on the line of action.

\begin{tabular}{lcccc}
\hline X-coordinate $(\mathrm{mm})$ & & & \\
\hline $\mathrm{A}$ & $\mathrm{B}$ & $\mathrm{C}$ & $\mathrm{D}$ & $\mathrm{E}$ \\
\hline $\mathrm{RS}$ & & & & \\
4.442 & 10.245 & 13.922 & 17.731 & 23.534 \\
$\mathrm{PM}$ & 10.251 & 13.882 & 17.732 & 23.47 \\
4.368 & & & & \\
\hline
\end{tabular}

AQ-AQ gear combination has a slightly thicker film thickness than the RS-RS gears.

\section{Discussion}

As shown in Fig. 10, due to the different elastic properties of PM and RS materials, the normal load distributions do not differ much despite the differences in the maximum contact stress for RS and PM gears. The RS-RS and PM-PM gear combinations have nearly the same sliding speed (Fig. 11). Furthermore, the difference in minimum lubricant film thickness between the gear combinations is small, as shown in Fig. 12. Hence, the influence of normal load distribution, sliding speed, and film thickness on PM gear transmission efficiency can be neglected.

Andersson et al. [12] showed that the decrease in average power loss of super-finished RS-RS gear combinations compared 

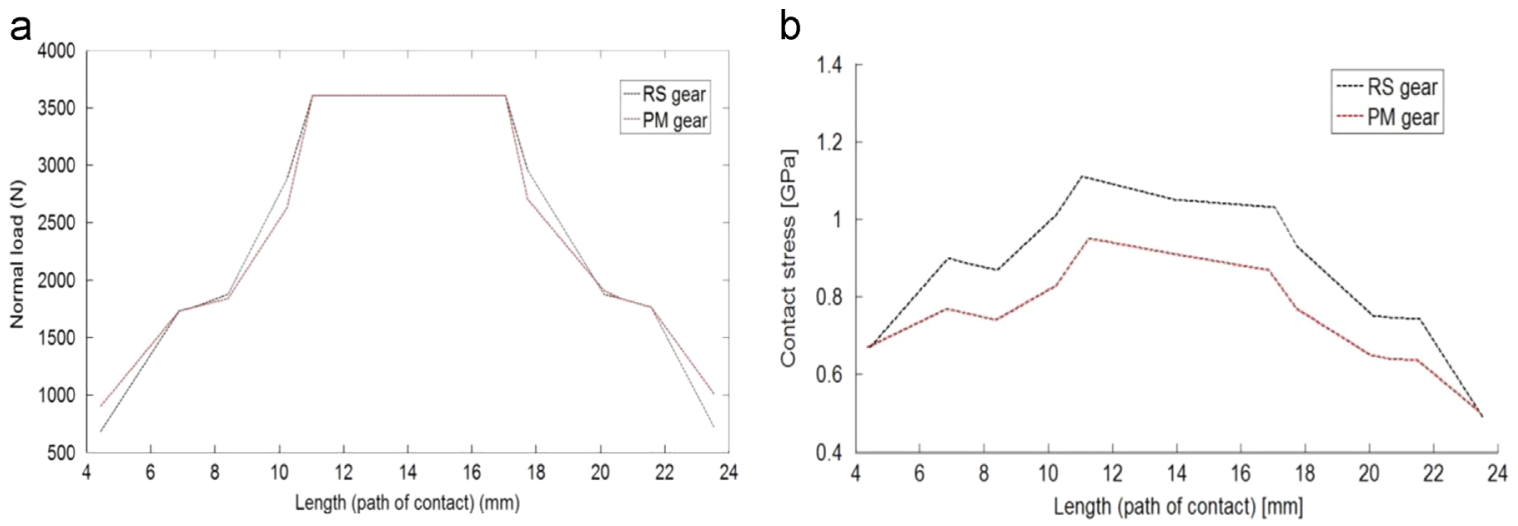

Fig. 10. Normal load (a) and maximum contact stress (b) of RS-RS and AQ-AQ gear combinations at load stage 7.
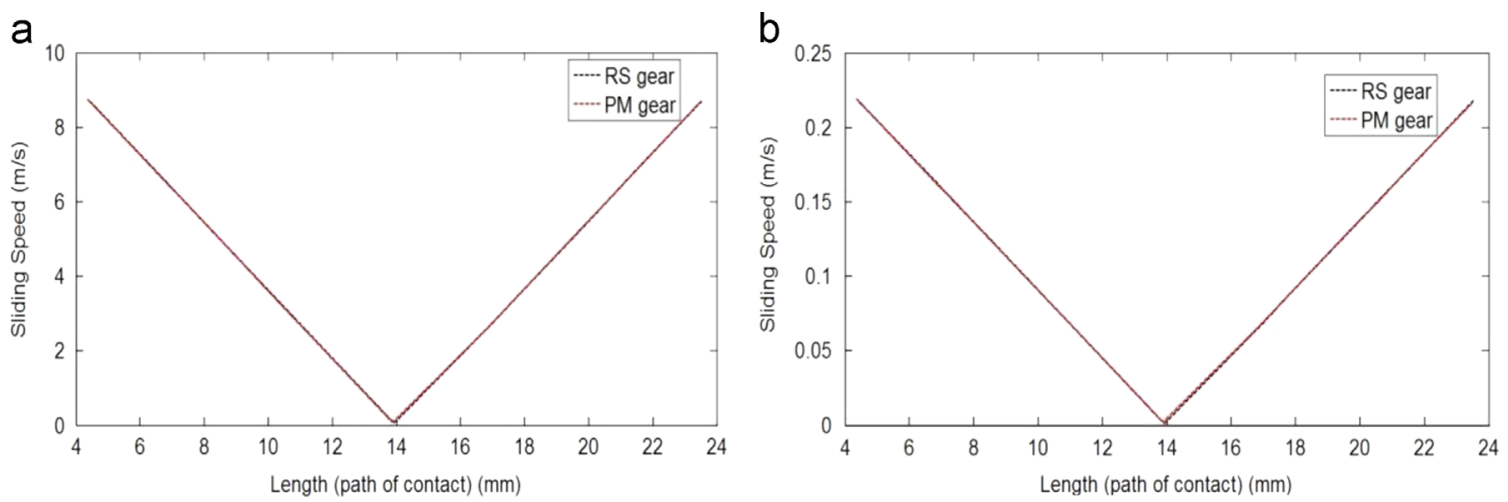

Fig. 11. The mated profiles sliding speed of RS-RS and AQ-AQ gear combinations at load stage 7, (a) $3479 \mathrm{rpm}$, (b) $87 \mathrm{rpm}$.
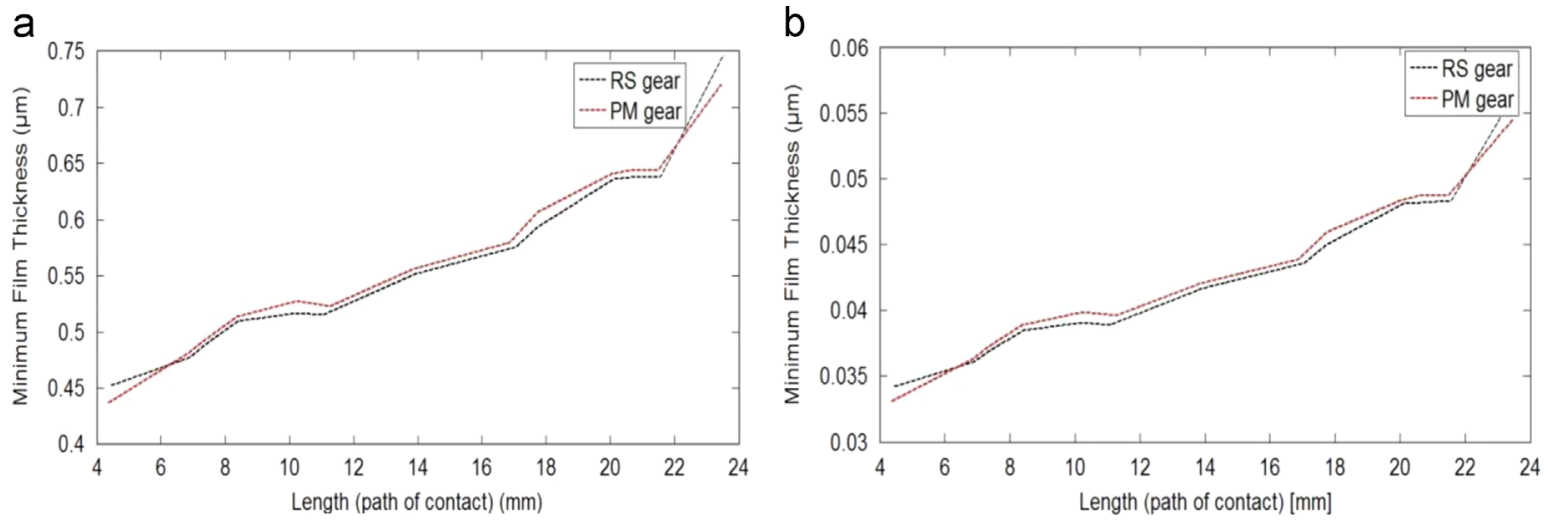

Fig. 12. Film thickness of RS-RS and AQ-AQ gear combinations at load stage 7, (a) $3479 \mathrm{rpm}$, (b) $87 \mathrm{rpm}$.

to ground gear surfaces is $60 \%$ and $33 \%$ for load stages 5 and 7 respectively at pitch line velocities between 3 and $20 \mathrm{~m} / \mathrm{s}$. This is mainly because fewer surface peaks are in contact for the superfinished gears. Note that the mechanism of the difference in efficiency between RS-RS and AQ-AQ ground gear combinations was studied in detail in [14], and will not be discussed here.

The gear mesh and total efficiency behavior of super-finished AQ-AQ gear combinations is the opposite of the RS-RS combinations. The average total efficiency at all loads is $22 \%$ higher for the ground AQ-AQ gear combination than for super-finished gears, and the average gear mesh efficiency at all loads is $39 \%$ higher than that of super-finished gears. Fig. 7 shows the 3D surface roughness and peak distribution of both ground and super-finished gears.
After the experiment the surface roughness and peak distribution of ground RS-RS, ground AQ-AQ and super-finished RS-RS have all become smoother than before the experiment. However, for the super-finished AQ-AQ gear combination, the surface roughness and peak distribution increased after the experiment.

In the SEM photos of ground RS-RS, ground AQ-AQ and superfinished RS-RS combinations, not much adhesive wear is visible (Fig. 9). As before, the trend is different for the AQ-AQ-superfinished combination, which clearly shows adhesive wear. One possible explanation for this phenomenon is a difference in the surface energy of the gear tooth interfaces. When two smoothly finished surfaces of the same material are forced together, the surface energy is completely determined by the adhesive energy, 
Table 9

Values of surface energy for different materials.

\begin{tabular}{llllll}
\hline Metal & $\gamma, \frac{\mathrm{J}}{\mathrm{m}^{2}}$ & Ceramics & $\gamma, \frac{\mathrm{J}}{\mathrm{m}^{2}}$ & Polymer & $\gamma, \frac{\mathrm{J}}{\mathrm{m}^{2}}$ \\
\hline $\mathrm{Fe}$ & 1.5 & $\mathrm{Al}_{2} \mathrm{O}_{3}$ & 0.8 & HDPE & 0.035 \\
$\mathrm{Cu}$ & 1.1 & $\mathrm{ZrO}_{2}$ & 0.53 & PMMA & 0.045 \\
$\mathrm{Al}$ & 0.9 & $\mathrm{TiC}$ & 0.9 & PA 6 & 0.05 \\
$\mathrm{Ni}$ & 1.7 & $\mathrm{ZrC}$ & 0.6 & PVC & 0.045 \\
$\mathrm{Ag}$ & 0.9 & - & - & PTFE & 0.018 \\
$\mathrm{~Pb}$ & 0.45 & - & - & - & - \\
$\mathrm{Cr}$ & 1 & - & - & - & - \\
\hline
\end{tabular}

$\mathrm{T}_{\gamma}=2 \gamma$, where $\gamma$ is the surface energy of material in contact [22]. Table 9 shows the values of surface energy for clean surfaces of different materials. The data are taken from [23] and [24].

Table 1 shows that there is $0.5 \% \mathrm{Ni}$ in AQ material gears and Table 8 shows that $\mathrm{Ni}$ has the highest surface energy of all the materials in Table 9. Furthermore, this $\mathrm{Ni}$ is undissolved in the PM gear material [14]. This implies that PM gears are likely to have a higher surface energy. Beek [22] showed that one efficient method of reducing the surface energy is to increase the surface topography. The ground PM gears with their comparably rougher surface together with their porosities are acting as oil reservoirs, which is beneficial from an energy efficiency perspective. However, in the case of the super-finished AQ-AQ gear combination, the surfaces are so smooth that the surface energy forces dominate and lead to adhesive material transfer. Further research is necessary, especially with alloying elements in super-finished powder metallurgic gears to decrease the surface energy.

\section{Conclusions}

Based on an experimental study in a FZG gear test rig combined with surface analysis of the gear tooth surfaces and simulation of the gear contact mechanics, the following conclusions can be drawn:

- The influence of elastic properties of powder metallurgy material on gear transmission efficiency in FZG gear geometry can be neglected.

- Gear efficiency is closely related to material combinations and surface roughness.

- The efficiency of the super-finished powder metallurgy material gear combination is lower than that of the ground combination due to adhesive material transfer. This is in contrast to the results from a super-finished regular steel gear combination.

\section{Acknowledgments}

Thanks are expressed to Dr. Michael Andersson and Marcus Persson from Höganäs $\mathrm{AB}$ for their technological support and discussions. This project was financially supported by Energimyndigheten, Höganäs $\mathrm{AB}$ and Swepart.

\section{References}

[1] Hohn BR, Michaelis K, Wimmer A. Low loss gears. Gear Technol 2007;24 (4):28-35.

[2] Magalhes L, Martins R, Locateli C, Seabra J. Influence of tooth profile and oil formulation on gear power loss. Tribol Int 2010;43(10):1861-71.

[3] Petry-Johnson TT, Anderson A, Kahraman A, Chase DR. Experimental investigation of spur gear efficiency. In: Proceedings of the ASME international design engineering technical conferences and computers and information in engineering conference DETC2007. 7; 2008. p. 747-57.

[4] Martins R, Seabra J, Brito A, Seyfert Ch, Luther R, Igartua A. Friction coefficien in FZG gears lubricated with industrial gear oils: biodegradable ester vs. mineral oil. Tribol Int 2006;39(6):512-21.

[5] Hohn BR, Michaelis K, Doleschel A. Frictional behavior of synthetic gear lubricants. In: Dalmaz G, editor. Tribology research from model experiment to industrial problem. Amsterdam: Elsevier; 2001.

[6] Xiao L, Amini N, Rosen B-G. An experimental study on the effect of surface topography on rough friction in gears. In: JSME International Conference on Motion and Power Transmission. Fukuoka, Japan; 15-17 2001. p. 547-52.

[7] Britton RD, Elcoate CD, Alanou MP, Evans HP, Snidle RW. Effect of surface finish on gear tooth friction. Trans ASME 2000;122:354-60.

[8] Bergseth E, Olofsson U, Lewis R, Lewis S. Effect of gear surface and lubricant interaction on mild wear. Tribol Lett 2012;48(2):183-200.

[9] Björling M, Larsson R, Marklund P, Kassfeldt E. Elastohydrodynamic lubrication friction mapping: the influence of lubricant, roughness, speed, and slide-toroll ratio, Proceedings of the IMechE 225 Part J: J Engineering Tribology.

[10] Xiao L, Rosen B-G, Amini N, Nilsson Per H. A study on the effect of surface topography on rough friction in roller contact. Wear 2003;254(11):1162-9.

[11] Sjöberg S, Sosa M, Andersson M, Olofsson U. A study of running-in and efficiency of ground gears. Tribology International, http://dx.doi.org/10.1016/j.tri boint.2015.08.045.

[12] Andersson M, Sosa M, Olofsson U. The effect of running-in on the efficiency of super-finished gears. Tribology International, http://dx.doi.org/10.1016/j.tri boint.2015.08.010.

[13] Li X, Sosa M, Olofsson U. A pin-on-disc study of the tribology characteristics of sintered versus standard steel gear materials. Wear 2015. http://dx.doi.org/ 10.1016/j.wear.2015.01.032i.

[14] Li X, Olofsson U. FZG gear efficiency and pin-on-disc frictional study of sintered and wrought steel gear materials. Tribology Letters, http://dx.doi.org/10. 1007/s11249-015-0582-6.

[15] Winter H, Michaelis K. FZG gear test rig: Description and possibilities, Coordinate European Council second international symposium on the performance evaluation of automotive fuels and lubricants, 1985.

[16] Andersson M, Sosa M, Sjöberg S, Olofsson U. Effect of assembly errors in backto-back gear efficiency testing. In: Proceedings of the international gear conference; 2014.

[17] Beiss P. Mechanische eigenschaften von sinterstählen. Tagungsband zum Symposium für Pulvermetallurgie: Material-Prozess-Anwendung Hagen 27; 2003.

[18] SKF. Rolling bearings catalogue. SKF group; 2012. p. 97-114.

[19] Jelaska D. Gears and Gear Drives, Wiley; 2012, 170

20] 〈http://www.kisssoft.ch/english/home/index.php〉.

[21] Dowson D, Higginson GR. Elasto-hydrodynamic lubrication: international series on materials science and technology, 23. Elsevier; 2014.

[22] Beek AV. Advanced engineering design. TU Delft 2009:155-8.

[23] Ramai DS, Demeioe LP, Mittal KL. Fundamentals of adhesion and interfaces. VSP; 1995.

[24] Rabinowicz E. Friction and wear of materials. 2nd edWiley; 1995. 